\title{
The Battle of SARA Politicization as a Threat to Virtual Public Spaces and Indonesian Cyber- Democracy (Semiotics Analysis on 2019 Presidential Election Campaign Narrative on Twitter between The Incumbent and The Opposite)
}

\author{
Fransiskus Emilus Dhosa Kadjuㄹ, Henni Gusfa ${ }^{2}$ \\ \{fransiskuskadju18@gmail.com ${ }^{1}$,henni.gusfa@mercubuana.ac.id²\} \\ Universitas Mercubuana, Jakarta, Indonesia ${ }^{12}$
}

\begin{abstract}
Currently Indonesia is slowly starting to enter the era of community 5.0 or also called integrative virtual community created by the help of big data technology. This phenomenon then affects all aspects of Indonesian people's lives, such as social, economic, cultural, and so on. Even virtual reality continues to expand in the lives of Indonesian people, because the development of new media makes the political domain come to switch to cyberspace. Not a few social media accounts are used as buzzers, both for upgrading coalition, or downgrading the political opponents. This is very visible in the campaign of the 2019 Presidential Election in Indonesia. That is why this research uses a critical paradigm with Critical Discourse Analysis (CDA) from Teun van Dijk to analyze the narratives of the political campaign at the 2019 Presidential Election critically concerning the construction of Indonesian democracy. As a theoretical basis, the author combines the concept of Lebenswelt by Jürgen Habermas and Zwischenraum by Hannah Arendt to develop the meaning of democracy participatory-substantive, which in practice today tends to put more priority on procedural aspects. The results showed that both the incumbent stronghold (Joko Widodo and Ma'ruf Amin), as well as the opposition (Prabowo Subianto and Sandiaga Uno) both use social media to amplify their political campaigns respectively. However, many supporting accounts from each faction actually use attacking campaigns in the form of propaganda, provocation, SARA, and Hoax. Each camp only focuses on mere procedural aspects with the aim to win, without providing good political education and democracy for the people of Indonesia. This then makes Indonesian democracy a thick style plurality, tolerance, and Unity in Diversity actually began to fade. In short, the narratives that were built during the 2019 Presidential Election campaign on Twitter made the public partly divided and certainly greatly threatens substantive democracy in Indonesia.
\end{abstract}

Keywords: 2019 Presidential Election, Political Campaign, Twitter, SARA Politization, Democracy, Bhinneka Tunggal Ika

\section{Introduction}

Disruption of public communication media and the technological developments that creates the society 5.0 in Indonesia has shaped a reality of new socio-politics known as cyber 
politics [1]. This momentum makes political practitioners must use conventional campaign strategies to campaign strategies based on media convergence [2]. As a result, political narratives, either conventional campaigns which are full of black campaigns, or expand into social media channels [3] [4]. The politics of constructive ideas for the good of Indonesia is in order umpteenth time because virality takes precedence.

The phenomenon of the Presidential Election (Pilpres) in the simultaneous general election on April 17, 2019, then thereby. The fight between the incumbent (Joko Widodo and Ma'ruf Amin) and the stronghold the opposition (Prabowo Subianto and Sandiaga Uno) appeared to be so viral on social media [5]. The successes teams and supporters of both camps competed to raise engagement to make his political narratives become trending topics. Even not a few antagonistic narratives such as hoax, SARA, and provocation are spread to influence public opinion and receive electoral incentives [6]. Started from the issue of radical Islam, infidels, until the rise of the PKI (The Communist Party of Indonesia) was used as a political weapon. This then makes the Indonesian public polarized inward two camps and at a more crucial level could threaten Indonesia's democracy synonymous with unity indifference [7].

This is the nadir of Indonesian democracy. Freedom without control and boundaries constitutional boundaries. This happens because of the narratives of the antagonism echoed by each camp so that supporters remain divided into two large polarizations. The virality aspect is preferred for winning, even by spreading hoax, provocation, and propaganda [8]. Therefore, the writer is interested in creating new media-based research specifically Twitter with the title: The Battle of SARA Politicization as a Threat to Virtual Public Spaces and Indonesian Cyber- Democracy (Semiotics Analysis on 2019 Presidential Election Campaign Narrative on Twitter between The Incumbent and The Opposite).

In this study, the author combines the concept of Lebenswelt Jürgen Habermas and Zwischenraum Hannah Arendt to build the meaning of democracy participatory-substantive, which in practice today tends to put more priority on procedural aspects.

\subsection{Lebenswelt as Locus of Rational Communicative}

Jürgen Habermas is the originator of communicative rational theory in the context of space public (Lebenswelt) which is the subject of debate among postmodern philosophers [9, pp. 128, 185]. Moreover, according to F. Budi Hardiman [10, pp. 198-199], the public sphere is not just physical space in the sense of an institution or organization legal. More than that, public space is a manifestation of communicative action citizens [11, p. 5]. Public sphere must be free, opened, and transparent without domination and intervention from any party including the authorities [12]. Here, communicative rational must fall into rational action in order to achieve the common good (bonum commune) in a shared world or Lebenswelt [11]. The concept of Lebenswelt or Habermas's public space is actually inspired by the concept of public space Hannah Arendt.

\subsection{Zwischenraum as Locus of Political Action}

Zwischenraum (intermediate space) is a typical Hannah Arendt thought. Arendt, inside Budi Hardiman [10] defines public space as intermediate space (Zwischenraum) to describe the shared space (world) in which humans can actualize political action within a framework of pluriformity. In space, this is the human gathering to discuss in freedom and diversity point of view for the sake of a particular matter and for the benefit of all. In this space too individuals relate their problems to the private sphere. Public space as the world brings people together and prevents them from mutual cooperation eliminate and dominate. Arendt 
states that the shared world makes it possible for humans to live together, a world that is among those who own it as shared property, a world in which there are plurality and freedom. Thus, politics is truly synonymous with action and freedom because politics is a space where freedom can manifest itself as reality worldly [13, p. 52].

Therefore, Arendt advocates a participatory democracy; not merely procedural as in representative concepts. Democracy participatory, in turn, produces a consensus that represents all aspirations citizens. Arendt offers participation from the community to escort the participant's leaders because thoughts and actions cannot be represented other than through dialogue, discussion, and public debate [14, p. 265].

\section{Research Method}

This study uses Critical Discourse Analysis from Teun A. van Dijk. In Discourse as Structure and Process [15, p. 2], Dijk based the analysis critical discourse on the three dimensions that make up the discourse namely text (language use), cognition social or intertextuality (the communication of beliefs), and social context or practice culture of a text (interaction in social situations). Then, Dijk "Ideology" [16, p. 193] stated, “... my approach is essentially multidisciplinary, and combine an analysis of linguistic, cognitive, social and cultural aspects of text and talk in context, and does so from a critical, socio-political perspective." Analyzing text, social cognition, and context will make researchers able to understand the meaning that develops in the practice of discourse comprehensively. In this case, Dijk [15] said, "the first focuses on the analysis of verbal structures and cognitive processes, the second on discourse as interaction in society."

The purpose of using this method is to analyze deeply about political campaign narratives (text and images) and extrinsic elements that make up the narrative or in the language of Van Dijk social cognition or intertextuality and social context culture. The purpose of the text is determined by the creator of the text, because the text was created with specific goals and objectives Dijk [15] saw, "discourse is generally different from each other, even when produced in similar social situations." Besides being determined by the creator of the text, the intent of the text can be seen and analyzed through context: the birth and existence of the text or the events underlying the existence of the text. In "Discourse as Structure and Process" [15], Dijk said that, “... in modern linguistic, discourse analysis may also begin with the analysis of a separate level of observable manifestations or expression, namely auditory sounds and visual marks (letters, figures, color, etc) on paper, boards, or computer screen."

\section{Results and Discussion}

\subsection{Text Analysis}

The 2019 Presidential Election is very thick with the feel of a virtual campaign. Textual analysis focuses on the narrative amplified by the official@jokowi and @prabowo accounts as the most engagement accounts that influence conversations on Twitter [17]. Be it @jokowi account and@prabowo, both using Twitter to campaign for themselves, even both of them are the most influential accounts of each cluster. Based on the textual narrative, it appears that both of them use strategy propaganda, where Jokowi through his official account tends to use narratives-narrative of optimism that Indonesia is currently starting to 
advance, while Prabowo is through his official account tends to attack the status quo that justice and prosperity have not distributed to Indonesian people.

The @Jokowi account makes the argument (create the framing) that Indonesia's economy in Indonesia is in a stable condition and infrastructure development in Indonesia too progressive during his leadership [18]. The narrative of optimism is very apparent from Jokowi's tweet on January 7, 2019 (see table listing figure 18). The @ Jokowi account wants to show and convey that the macroeconomy of Indonesia in 2018 until the beginning of 2019 is in good condition. The number of economic growths in 2018 of $5.15 \%$ with an inflation rate below $3.5 \%$ will certainly have an impact on the exchange rate of the rupiah against the dollar where the value of the rupiah is stable [19] [20]. This tweet is also a positive campaign model because it shows more of Jokowi's success in developing Indonesia to upgrade acceptability and Jokowi's electability, without attacking political opponents and downgrading him [21].

In the other side, @prabowo account uses the opposite narrative to @jokowi. If @jokowi uses optimistic narratives that Indonesia has advanced in his leadership, then @prabowo is the opposite, namely pessimistic narratives. According to @Prabowo, all people are suffering in Jokowi's era of president. Moreover, he (Prabowo) fought for the people, not for certain personal or group interests and the struggle to win the 2019 Presidential Election to support people who have suffered for a long time (see table listing figure 19 and 20).

\subsection{Intertextuality}

In the virtual campaign using Twitter, we found that the conversations that were circulating were very much dominated by SARA narratives, where each camp used it to attack each other [22]. The battle of SARA, based propaganda testimonials is visible in both accounts [23]. The @ Pababowo account in the campaign also once said thanks to the scholars who support it, which is a type of testimonial propaganda [24]. The @Prabowo account puts religious leaders and scholars on the front of the utterance thanks for showing the public that he is supported by figures Islam (see table 17) [25].

In addition to the @ Prabowo account, political campaigns carry a more visible religious name echoed by accounts supporting the opposition. Multiple supporting accounts PrabowoSandi actively amplifies religious issues (see a table list of Figures 1 to 7 ). The tweets that are religious politicized shows that religious issues have been used as political tools to win the 2019 Presidential Election. Support Ustadz Abdul Somad (UAS), Ustadz Adi Hidayat (UAH), AA Gym, and other clerics to Prabowo were used by accounts supporting the opposition to attract sympathy from the majority of Indonesian people who are Muslims. Even these accounts also did not hesitate to campaign for Prabowo as the President of the ulama's choice and is a president who has been determined by God (see a table list of Figures 1 to 7). Here it appears that the account supports Prabowo using a testimonial propaganda strategy, which is using religious figures as a weapon to grade support for Prabowo and at the same time downgrade of support for Jokowi [26, p. 47].

Against this tweet, the account @Jokowi just replied that God's will is in above all (see a table list in Figure 8). Through his account, Jokowi wants to say that he could become the Mayor of Solo, then the Governor of DKI Jakarta, and become the president in 2014 was because of God's plans and will. Without the will of God, he could not have achieved that, considering he was an ordinary person, no from the elite, and only ordinary village children. Here, Jokowi's inner culture appears as an "eastern" person who believes in transcendental forces that transcend human efforts. Jokowi believes that above political culture is always changing, there is an inner self-culture that stays; that's the transcendental power. In the 
context of religion, Jokowi wants to represent the inner culture as a form of obedience and belief in God's righteousness; that all political efforts will be achieved if desired by Allah. When not desired by God, then any amount of human effort will fail. Jokowi too here represents himself as a devout Muslim. In addition, Jokowi in some of his tweets showed his closeness with religious leaders and Muslim organizations (see table listing figures 9 through 11). Jokowi wants to reframe the accusations of the accounts supporting supporters of the opposition himself Nhadatul Ulama and anti-Muslim by showing its closeness to the ulama and Muslims. He also wants to present himself as a Muslim who obedient [27].

But unfortunately, the supporting accounts from each camp are actually very aggressive conduct direct attacking campaigns to attack and delegitimize political opponents with narratives smelling SARA. The account @,Adra_silent, for example, said that Jokowi is a religious manipulator (see table listing figure 12) is an example of how the 2019 Presidential Election campaign on Twitter has been obscured by hate speech narratives which is actually not allowed in public spaces [28]. In addition, the @ Jokoedy6 account tweet said that Jokowi was not from NU and that no Muslim was very thick nuances of the antagonism (see table listing figure 13). Next, tweets @pakaipeci (see a table list in figure 14), as a support opposition camp, showing how supporters of the opposition camp tried to pull the acceptability of the Muslim community [29], that if you want Kyai protected and want tahlilan event is not executed, then Prabowo is the solution.

In addition to religious issues, Jokowi was also attacked with other antagonistic narratives namely that he is a descendant of the PKI, that he also supports LGBT, and that he is "Foreign henchmen," as elaborated before. This tweet also contains propaganda namecalling to Jokowi with the aim to downgrade Jokowi. Not only the opposition who attacked Jokowi with the SARA issue, Prabowo too seemed to get an attacking campaign from the accounts of the incumbent supporters. Attacking The SARA-pitched campaign was very visible when this account said that Prabowo was of Chinese Christian descent but acted as if he were a true Muslim (see a table listing picture 15). Other affiliate accounts also even directly attacked Prabowo with said that Prabowo was of Chinese-Kafir descent because his father was a descendant of China and his mother are Christians. The account also even displayed photos of dad and dad Prabowo's mother added the hashtag \#PrabowoKeturunanKafir (\#PrabowoDescendantsOfInfidels) (see table 16 in figure 16) [30]. Moreover, Prabowo was a serious human rights violator in 1998 [31]

In the narrative section on Religion, Ethnicity, Race, and Class as is elaborated by the researchers above, it appears that there is no single narrative that is rational communicative. Each faction instead made a narrative that was increasingly devout Indonesian virtual public space [32]. Of course, sectarian narratives are dividing the unity of the Unitary Republic of Indonesia, such as the politicization of religion, issues of the PKI and infidels, and tribal issues that carry the name "China" gained a large place in the section this [33]. In the view of political agonism, precisely divisive narratives like this there shouldn't be. If it still exists, then living together indifference will not materialize [34].

From this SARA battle, it appears that the supporting accounts of both camps more massive use of the name-calling strategy, which is one technique propaganda by giving bad labels to ideas, people, objects, policies, with the aim that audiences reject political opponents without examining reality [35] [36, pp. 134-135]. The hashtag \#Jokowigagal (\#JokowiFailed) and the quote "genderuwo politician" (Genderuwo is a kind of satan from Java's tale) form name-calling Prabowo's supporting account to Jokowi. While the quote "Prabowo Chinese descendants of infidels "is a form of name-calling for Jokowi's supporters to Prabowo. 


\subsection{Socio-Culture}

The political context of the birth of sara narratives, as elaborated in the intertextuality analysis, is the political event of the 2019 Presidential Election [37]. In a practical political context, losing and winning are the main focus [38]. So that each camp must try to upgrade the supported figures [39]. Not only that, the support team often conducts attacking campaigns to down grade political opponents [40]. The @Jokowi account is the official account of the President of the Republic of Indonesia for the 2014-2019 period who again ran for the incumbent Presidential Election in the 2019 Presidential Election. While the @ Prabowo account is the official account of Prabowo Subianto who is the challenger of Jokowi for the second time [41]. In 2014, Prabowo who was partnered with Hatta Rajasa had challenged Jokowi, who was then paired with Jusuf Kalla [42]. At that time, Jokowi-Kalla won the Presidential Election and became the President and Vice President of 2014-2019, while the defeated Prabowo chose to become the opposition. The both use social media [43] to campaign their agenda [44].

Now, in the 2019 Presidential Election, Prabowo has become Jokowi's opponent and all of supporters account using SARA narratives [45]. Of course, the SARA narrative used then divide the unity of Indonesian society which upholds Bhinneka Tunggal Ika, diversity and tolerance [46]. Even friendships and fraternities break up and break down because of different political supports [47].

\subsection{Diversity of SARA as Indonesian Democratic's identity}

Social identity is "conditio per quam" or conditions inherent in life togetherness and neglect with others. However, when this social identity politicized for certain purposes, even to the point of having an inter-identity tension social, then this must be avoided or in other words, "sine qua non" (there should not be) [48, pp. 108-112]. A wave of identity politicization arises when people use identity issues certain in political events, whether it's religion, race, ethnicity, and class, to get support from certain identities that are judged to be key audiences or majority [49]. Simply put, identity politicism removes the word "we" and views everything from the perspective of "we are dealing with them" [50]. Basic politicization identity is the sentiment of a group or group that feels harmed, insulted [51].

Conceptually, polarization, as happened in the 2019 Presidential Election, is a type of polarized leader and not polarized values [52]. Polarized leaders occur because the community sees more of who the leader is supported, not what the idea is to be implemented to build the nation [53]. Whereas polarized values are a polarization that occurs because of a "fact duel" rationally, not emotionally [54]. Of course, the fact duel in question is a duel of factual ideas about how realizing Bomun commune or the common good in civil society [55]. Accordingly, conceptually, this duel of rational facts is known as political agonism; a condition that is both hopeful and challenging in practical political contestation in Indonesia [48].

What happened in Indonesia as elaborated above is the same as what happened in the 2016 United States Presidential Election [56]. Many digital political operators spreading rumors, speculation, hoaxes, racial intolerance, even propaganda precisely muddy the state of political reality and the reality of society [57] [58, p. 343]. The goal is: to influence public opinion and achieve victory in the presidential election 2019. But as a result, SARA-based hatred between citizens has eroded deeply by the two poles of political polarization in the 2019 Presidential Election, until the marginalization and dehumanization of fellow citizens [59]. Community and supporters respectively each camp is not taught to use good and true 
narratives during times of political campaign [60]. This is what then makes citizens democratic awareness properly and properly eliminated. Not the common sense and politics of unity that results, but rather divisions and the formation of mass action produced by political propaganda [48].

Multiculturalism, which in the context of Indonesia is more beautifully framed in the motto of Unity in Diversity is slowly fading because of the affiliative ideology of each camp against identity politicization. In other words, Unity in Diversity as the spirit of Indonesian democracy which becomes the common thread binding the pluralist factum in Indonesia was eroded by a wave of political antagonism in the form of identity politicization which is so big in the 2019 Presidential Election [61]. This certainly makes a multicultural Indonesia wrapped in a spirit of tolerance that will not be maintained [62].

Robert W. Hefner in his book "The Politics of Multiculturalism" [63, pp. 253-254] saw the differences and multiculturalism as reality and reason for mutual complementarity between strengths and weaknesses, not as an excuse for mutual cooperation to dominate each other. This means that multiculturalism is only possible if cultural plurality, customs, religion, and customs are recognized as a reality in the togetherness of life [64].

\subsection{SARA Politization is a Threat to Virtual Public Spaces and Indonesian Cyber- Democracy}

For that reason, things that should exist besides amplification of narratives about multiculturalism, in public life is a narrative about tolerance [65]. Tolerance in the true sense is "free" and "conscious" acceptance of the fact that others are a different fellow, maybe in race, religion, creed, and ideology. Do not let politics practically destroy the joints of life together in Indonesia [66]. If this view is placed in the context of Unity in Diversity, then multiculturalism and tolerance must be at the core of every political narrative, both by the stronghold incumbent and opposition camp. To arrive at the active tolerance stage, it is needed awareness of social identity, that is, even though social identity is different, everything is part of NKRI which is pluriform [67]. Through building social awareness, all citizens who are socially diverse can build a citizenship country [68]. Indonesian democracy will be on the right track if Bhineka Tunggal Ika is understood mutually and reciprocally in the context of identity diversity and social awareness [24]. Because dialectics are mutual, reciprocal, and equal deep plurality is only possible in the spirit of tolerance which is the fruit of social awareness [48].

From the table in the previous discussion, it appears that researchers find it very difficult to find agonistic narratives because both the incumbent camp and the opposition camp are still using antagonistic narratives to attack political opponents [69]. Narrative fights the 2019 presidential election on Twitter shows that it is not only to grade acceptability and the electability of the strongholds it supports through positive campaign narratives, however Supporting accounts actually attack each other with its attacking campaign strategy to downgrade political opponents [70]. In addition to the @jokowi account that builds narration optimistic through propaganda and @prabowo that builds pessimistic narratives through propaganda to get attention, acceptability, and public electability, distribution narratives of political campaigns by supporting accounts of each camp and discourse that developed in the twitter, even more, shows the side of antagonism [71] [72].

Incumbent attacks the opposition, and instead the opposition attacks the incumbent. Even antagonistic narratives such as hoax, SARA, and provocation, as elaborated on the results of this research, often become the main weapon to win the 2019 Presidential Election [73]. There is no jury who stood in the middle, because each camp claimed to be its bearer the 
truth, and whatever is said by political opponents is wrong. Narratives the antagonism which was amplified through hashtags actually poisoned the interested public through social media (twitter) [44]. If antagonistic narratives like the one above are still used in every practice political campaigns on social media, the public's critical reason will be eroded so that reality Indonesian people will continue to experience division as happened in the Presidential Election 2014 and is happening in the 2019 Presidential Election, and it will probably continue to occur in momentum subsequent political contestation [41] [70]. The contestation may be finished, but social cognition will continue to be divided because of its antagonistic politics acted on social media [74]. In other words, if agonistic politics is not applied in the media social, then the community will be banal in carrying out online marginalization, cyberbullying, hate speech, and body-shaming as they appear on Twitter [75], even on higherlevel, they can be provoked and mobilized to take action destructive actions in the offline area [76].

\section{Conclusions}

The results of this study indicate that in the political domain of society 5.0 of Indonesian, both Jokowi and supporters Prabowo still uses SARA narratives (Ethnic, Religion, Race, and groups), innovators, and propaganda, both for attacking political opponents and degrading them, as well as to grade support voter community towards each candidate supported [77]. The narratives are this show then creates polemic in the community and is interesting them into polemic folds. The community then split into two; only one of Jokowi's supporters, other supporters Prabowo. Even anti-democratic narratives such as hoax, SARA, and provocation are often the main weapons for the deviation of the 2019 Presidential Election.

If this continues to be maintained within the scope of cyber-politics, then reality Indonesian people will continue to experience division and are easily provoked to mobilize destructively. Even marginalization of faction supporters' certain things can happen. This situation can threaten Indonesian cyber democracy in the era of society 5.0.

\section{References}

[1] D. S. Rajesh Bose, Raktim Kumar Dey, Sandip Roy, “Analyzing Political Sentiment Using Twitter Data," in Proceedings of Information and Communication Technology for Intelligent Systems (ICTIS), 2018, pp. 427-436.

[2] L. Vergeer, M., \& Hermans, "Campaigning on Twitter: Microblogging and Online Social Networking as Campaign Tools in the 2010 General Elections in the Netherlands," J. Comput. Commun., vol. 18, no. 4, pp. 399-419, 2013.

[3] A. Jungherr, "Twitter Use in Election Campaigns: A Systematic Literature Review," J. Inf. Technol. Polit., vol. 13, no. 1, pp. 72-91, 2016.

[4] K. Saddhono, A. Hasibuan, and M. I. Bakhtiar, "Facebook as A Learning Media in TISOL (Teaching Indonesian to Speakers of Other Languages) Learning to Support the Independency of Foreign Students in Indonesia,” J. Phys. Conf. Ser., vol. 1, 2019.

[5] M. Budiharto, W., \& Meiliana, "Prediction and Analysis of Indonesian Presidential Election from Twitter using Sentimen Analysis," Big Data J. Springer, vol. 5, no. 51, pp. 1-10, 2018.

[6] K. Karppi, T., \& Crawford, "Social Media, Financial Algorithms and the Hack Crash," J. Theory, Cult. Soc., vol. 0, no. 0, pp. 1-20, 2015.

[7] B. \& D. M. Chaitanya, "Text Categorization Using Sentiment Analysis," in Proceeding of International Conference on Computational Science and Applications, 2020, pp. 361-368.

[8] P. N. Woolley, S. C., \& Howard, "Political Communication, Computational Propaganda, and 
Autonomous Agents Introduction,” Int. J. Commun., vol. 10, pp. 4882-4890, 2016.

[9] F. B. Hardiman, Demokrasi Deliberatif: Menimbang Negara Hukum dan Ruang Publik dalam Teori Diskursus Jurgen Habermas. Yogyakarta: Kanisius, 2009.

[10] F. B. Hardiman, Ruang Publik: Melacak "Partisipasi Demokratis" dari Polis sampai Cyberspace. Yogyakarta: Kanisius, 2010.

[11] R. C. Holub, Jürgen Habermas: Critic in The Public Sphere. London: Routledge, 1991.

[12] Habermas, Between Facts and Norms: Contributions to a Discourse Theory of Law and Democracy. Cambridge: Polity Press, 1996.

[13] H. Arendt, The Human Condition. Chicago: The University of Chicago Press, 1958.

[14] H. Arendt, On Revolution. London: Penguin Books, 1965.

[15] T. A. Dijk, Discourse as Structure and Proces. London: Sage Publications, 1997.

[16] T. A. Dijk, Ideology: A Multidisciplinary Approach. London: Sage Publications, 1998.

[17] P. Pak, A., Paroubek, "Twitter as a corpus for sentiment analysis and opinion mining," in Proceedings of the Seventh International Conference on Language Resources and Evaluation (LREC'10), 2010, pp. 1320-1326.

[18] Arief Ashory Yusuf \& Andy Summer, “Growth, Poverty, and Inequality under Jokowi,” Bull. Indones. Econimic Stud., vol. 51, no. 3, pp. 323-348, 2015.

[19] Eve Warburton, "Jokowi and the New Developmentalism," Bull. Indones. Econimic Stud., vol. 52, no. 3, pp. 297-320, 2016.

[20] A. Bennett, W. L., \& Segerberg, "Digital Media and The Personalization of Collective Action: Social technology and the organization of protests against the global economic crisis," J. Information, Commun. Soc., vol. 14, no. 6, pp. 770-799, 2011.

[21] T. P. Power, "Jokowi's Authoritarian Turn and Indonesia's Democratic Decline," J. Bull. Indones. Econ. Stud., vol. 54, no. 3, pp. 307-338, 2018.

[22] D. Loader, B. D., \& Mercea, "Networking Democracy?: Social media innovations and participatory politics," J. Information, Commun. Soc., vol. 14, no. 6, pp. 757-769, 2011.

[23] O. A. Attarwala A, Dimitrov S, "How efcient is Twitter: Predicting 2012 US Presidential elections using Support Vector Machine via Twitter and comparing against Iowa Electronic Markets," in Intelligent Systems Conference (IntelliSys), 2017, pp. 7-8.

[24] R. W. Hefner, "The Study of Religious Freedom In Indonesia," J. Rev. Faith Int. Aff., vol. 11, no. 2, pp. 18-27, 2013

[25] R. W. Hefner, "Whatever Happened to Civil Islam? Islam and Democratisation in Indonesia, 20 Years On," Asian Stud. Rev., vol. 43, no. 3, pp. 375-396, 2019.

[26] D. Nimmo, Komunikasi Politik: Komunikator, Pesan, dan Media. Bandung: Remaja Rosdakarya, 1993

[27] A. Ahyar, M., \& Alfitri, "Aksi Bela Islam: islamic clicktivism and the new authority of religious propaganda in the millennial age in Indonesia,” Indones. J. Islam Muslim Soc. 9 (1), 1-29., vol. 9, no. 1, pp. 1-9, 2019.

[28] S. P. Le H, Boynton GR, Mejova Y, Shafq Z, "Bumps and bruises: mining Presidential campaign announcements on Twitter," in Proceedings of the 28th ACM conference on hypertext and social media, 2017, pp. 215-224.

[29] Abdil Mughis Mudhoffir, "Islamic Militias and Capitalist Development in Post-Authoritarian Indonesia,” J. Contemp. Asia, vol. 47, no. 4, pp. 495-514, 2017.

[30] O. Davidov, D., Tsur, "Rappoport a: enhanced sentiment learning using twitter hashtags and smileys," in Proceeding of the 23rd International Conference on Computational Linguistics, 2010, pp. 241-249.

[31] Katharine McGregor \& Ken Setiawan, "Shifting from International to 'Indonesian' Justice Measures: Two Decades of Addressing Past Human Rights Violations," J. Contemp. Asia, vol. 49, no. 5, pp. 837-861, 2019.

[32] D. F. Campbell, "Cyber-Democracy," in Cyber-Development, Cyber-Democracy and CyberDevense, E. G. C. D. F. C. M. P. Efthymiopoulos, Ed. Berlin: Springer, 2014, pp. 113-116.

[33] V. Bakliwal, A., Arora, P., Madhappan, S., Kapre, N., Singh, M., Varma, "Mining sentiments from tweets," in Proceeding of the WASSA'12 in Conjunction with ACL'12, 2012, pp. 11-18. 
[34] E. A. A. Agrawal D, Budak C, "Information diffusion in social networks: observing and influencing societal interests," in Proceedings of VLDB'11, 2011.

[35] D. M. \& V. R. H. Rachael Diprose, "Two Decades of Reformasi in Indonesia: Its Illiberal Turn,” J. Contemp. Asia, vol. 49, no. 5, pp. 691-712, 2020.

[36] G. G. Heryanto, Media Komunikasi Politik. Yogyakarta: IRCiSoD, 2018.

[37] J. Albright, "Welcome to the Era of Fake News," J. Media Commun., vol. 5, no. 2, pp. 87-89, 2017.

[38] B. Anderson, "Tweeter-in-Chief: A Content Analysis of President Trump's Tweeting Habits," Elon J. Undergrad. Res. Commun., vol. 8, no. 2, pp. 36-47, 2017.

[39] M. A. Firmansyah, "Kampanye Pilpres 2014 dalam Konstruksi Akun Twitter Pendukung Capres," J. Messenger, vol. 9, no. 1, pp. 79-90, 2017.

[40] O. C. Frasier, "The 2017 French Presidential Campaign on Twitter," in The Twelfth International AAAI Conference on Web and Social Media (ICWSM), 2018, pp. 501-510.

[41] E. Aspinal \& M. Mietzner, "Indonesian Politics in 2014: Democracy's Close Call," Bull. Indones. Econimic Stud., vol. 50, no. 3, pp. 347-369, 2014.

[42] G. A. Suraya, "The President of The people's Choice in the 2014 Election on Twitter," J. Univ. Paramadina, vol. 12, no. 1, pp. 1290-1318, 2015.

[43] G. N. Adamic L, "The political blogosphere and the 2004 U.S. election: divided they blog," in Proceedings of the 3rd international workshop on link discovery, 2005, pp. 36-43.

[44] S. Kholid, A., Husein, R., Mutiarin, D., \& Listiya, "The Influence of Social Media Towards Student Political Participation During the 2014 Indonesian Presidential Election," J. Gov. Polit., vol. 6, no. 2, pp. 246-264, 2015.

[45] B. Mietzner, M., \& Muhtadi, "Explaining the 2016 Islamist Mobilisation in Indonesia: Religious Intolerance, Militant Groups and the Politics of Accommodation," Asian Stud. Rev., vol. 42, no. 3, pp. 479-497, 2018.

[46] P. Marshall, "The Ambiguities of Religious Freedom in Indonesia,” J. Rev. Faithand Int. Aff., vol. 16 , no. 1 , pp. 85-96, 2018.

[47] D. G. and A. S. Jyoti R, Samarth S, "Election result prediction using Twitter sentiment analysis," in International conference on inventive computation technologies (ICICT), India, 2016, pp. $1-5$.

[48] D. C. Marietta, M., \& Barker, One Nation, Two Realities: Dueling Facts in Americans Democracy. New York: Oxford University Press, 2019.

[49] P. L. Francia, "Free Media and Twitter in the 2016 Presidential Election: The Unconventional Campaign of Donald Trump," Soc. Scince Comput. Rev., vol. 20, no. 10, pp. 1-16, 2017.

[50] L. Pedersen, "Religious Pluralism in Indonesia," Asia Pasific J. Anthropol., vol. 17, no. 5, pp 387-398, 2016.

[51] S. C. McGregor, "Twitter as a tool for and object of political and electoral activity: Considering electoral context and variance among actors,” J. Inf. Technol. Polit., vol. 14, no. 2, pp. 154-167, 2017.

[52] T. and J. Y. Nasukawa, "Sentiment analysis: Capturing favorability using natural language processing," in Proceedings of the 2nd Intl. Conf. on Knowledge Capture, 2003.

[53] Y. P. Aggarwal CC, Han J, Wang J, "A framework for clustering evolving data streams," in Proceedings of VLDB'03, 2003, pp. 81-92.

[54] G. Enli, "Twitter as arena for the authentic outsider: exploring the social media campaigns of Trump and Clinton in the 2016 US presidential election," Eur. J. Commun., vol. 32, no. 1, pp. 50-61, 2017.

[55] N. P. Gaumont, "Reconstruction of the socio-semantic dynamics of political activist Twitter networks-Method and application to the 2017 French presidential election," PLoS One, vol. 13, no. 9, pp. 1-53, 2018.

[56] U. C. Yaqub, "Analysis of political discourse on twitter in the context of the 2016 USpresidential elections," Gov. Inf. Q., vol. 34, no. 4, pp. 613-626, 2017.

[57] G. Mamgain, N., Mehta, E., Mittal, A., Bhatt, "Sentiment analysis of top colleges in India using twitter data," in In: International Conference on Computational Techniques in 
Information and Communication Technologies, 2016, pp. 1-6.

[58] A. Sudibyo, Jagad Digital: Pembebasan dan Penguasaan. Jakarta: Kepustakaan Populer Gramedia, 2019.

[59] J. Zebracki, M., \& Luger, "Digital Geographies of Public Art: New Global Politics," Hum. Geogr., vol. 43, no. 5, pp. 890-909, 2018.

[60] R. M. Soler JM, Cuartero F, "Twitter as a tool for predicting elections results," in IEEE/ACM International Conference on advances in social networks analysis and mining (ASONAM), 2012, pp. 1194-1200.

[61] N. Colbran, "Realities and challenges in realising freedom of religion or belief in Indonesia," Int. J. Hum. Rights, vol. 14, no. 5, pp. 678-704, 2010.

[62] I. Ritonga, R., \& Syahputra, "Citizen Jurnalism and Public Participation in the Era of New Media in Indonesia: From Street to Tweet," J. Media Commun., vol. 7, no. 3, pp. 79-90, 2019.

[63] R. W. Hefner, The Politics of Multiculturalism: Pluralism and Ciizenship in Malaysia, Singapore, and Indonesia. Honolulu: Univeirsity of Hawaii Press, 2001.

[64] K. Hamayotsu, "The Limits of Civil Society in Democratic Indonesia: Media Freedom and Religious Intolerance," J. Contemp. Asia, vol. 43, no. 4, pp. 658-677, 2013.

[65] J. V. . T. P. Dijck, "Understanding Social Media Logic," Media Commun., vol. 1, no. 1, pp. 2 14,2013

[66] M. Allcott, H., \& Gentzkow, "Social Media and Fake News in the 2016 Election," J. Econ. Perspect., vol. 31, no. 2, pp. 21-36, 2017.

[67] D. M. Bourcheir, "Two Decades of Ideological Contestation in Indonesia: From Democratic Cosmopolitanism to Religious Nationalism,” J. Contemp. Asia, vol. 14, no. 5, pp. 713-733, 2019

[68] A. Bennett, W. L., \& Segerberg, "The Logic of Connective Action: Digital media and the personalization of contentious politics," J. Information, Commun. Soc., vol. 15, no. 5, pp. 739-768, 2012.

[69] M. Lim, "Freedom to hate: social media, algorithmic enclaves, and the rise of tribal nationalism in Indonesia," J. Crit. Asian Stud., vol. 49, no. 3, pp. 411-427, 2017.

[70] B. A. . K. K. D. W. Conway, "The Rise of Twitter in the Political Campaign: Searching for Intermedia Agenda Setting Effects in the Presidential Primary," J. Comput. Commun., vol. 20, no. 4, pp. 363-380, 2015

[71] B. M. \& E. W. Edward Aspinall,Diego Fossati, "Elites, masses, and democratic decline in Indonesia," Democratization, vol. 27, no. 4, pp. 505-526, 2020.

[72] H. Molaei, "Discursive opportunity structure and the contribution of social media to the success of social movements in Indonesia," J. Information, Commun. Soc., vol. 18, no. 1, pp. 94-108, 2015.

[73] M. I. Farisi, "Social Media and the Emerging of People's Participation into the Political and Democratic Process of Indonesia: The Case of Act for Regional Leaders Election," TAWARIKH J. Hist. Stud., vol. 11, no. 1, pp. 43-64, 2019.

[74] S. Boullianne, "Social media use and participation: a meta-analysis of current research," J. Information, Commun. Soc., vol. 18, no. 5, pp. 524-538., 2015.

[75] I. M. W. Andranik Tumasjan, Timm O. Sprenger, Philipp G. Sandner, "Predicting Elections with Twitter: What 140 Characters Reveal about Political Sentiment," in Proceedings of the Fourth International AAAI Conference on Weblogs and Social Media, 2010, pp. 178-185.

[76] F. Shiraz, "Social Media and The Social Movements in The Middle East and North Africa A Critical Discourse Analysis," J. Inf. Technol. People, vol. 26, no. 1, pp. 28-49, 2013.

[77] A. M. Ibrahim M, Abdillah O, Wicaksono AF, "Buzzer detection and sentiment analysis for predicting Presidential election results in a Twitter Nation," in IEEE international conference on data mining workshop, 2015, pp. 1348-1353. 